J. Northw. Atl. Fish. Sci., Vol. 22: 249-257

\title{
Estimated Fish Consumption by Hooded Seals (Cystophora cristata), in the Gulf of St. Lawrence
}

\author{
M. O. Hammill \\ Maurice Lamontagne Institute, P. O. Box 1000 \\ Mont-Joli, Quebec, Canada G5H 3Z4 \\ C. Lydersen \\ Norwegian Polar Institute, P. O. Box 399 \\ N-9001 Troms $\varnothing$, Norway \\ K. M. Kovacs \\ Department of Biology, University of Waterloo \\ Waterloo, Ontario, Canada N2L 3G1 \\ and \\ B. Sjare \\ Northwest Atlantic Fisheries Centre \\ P. O. Box 5667, St. John's, Newfoundland, Canada A1C 5X1
}

\begin{abstract}
Fish consumption by hooded seals (Cystophora cristata) in the Gulf of St. Lawrence was estimated by bringing together information on individual energy requirements, population size, distribution and diet composition. Aerial surveys indicated that pup production had increased from $2006(S E=190)$ in 1991 to $3978(S E=974)$ in 1994 . A Leslie Matrix population model suggested that the population had increased from $10000-$ 11000 animals in 1991 to $11000-16000$ animals in 1995 , depending on the mortality rates used in the model. Individual daily energy requirements were estimated using the daily energy requirement, a daily growth increment, and the basal metabolic rate. Summing individual energy requirements over the period that hooded seals are thought to be in the Gulf of St. Lawrence, gave an increase in total fish consumption from 5 100-5 600 tons in 1991 to 5 600-8 400 tons in 1995. Assuming that the diet of the Gulf of St. Lawrence hooded seals was similar to that of animals collected off the Newfoundland coast, much of this consumption would have probably consisted of Greenland halibut (Reinhardtius hippoglossoides) and redfish (Sebastes sp.).
\end{abstract}

Key words: distribution, feeding, food, Gulf of St. Lawrence, hooded seals

\section{Introduction}

The decline in several Northwest Atlantic groundfish stocks, most notably Atlantic cod ( $\mathrm{Ga}$ dus morhua) stocks, has been attributed to a combination of overfishing, unfavourable environmental conditions and possibly predation (Anon., 1995). This decline resulted in the closure of several commercial fisheries. Although some closures took place as early as 1992 some stocks e.g. northern cod off northeastern Newfoundland (in Div. $2 \mathrm{~J}+3 \mathrm{KL}$ ) show little sign of recovery (Anon., 1995).
In the absence of fishing mortality, other factors that may interfere with the recovery of Northwest Atlantic fish stocks include unfavourable environ-mental conditions, competition for common prey species or direct predation by seals or other piscivorous predators. In order to examine the impact of predation on the recovery of a fish stock, information on total natural mortality and the proportion of that mortality that can be attributed to individual predator species is required. One component of this analysis is to estimate total consumption by different predator species. This 
requires information on population size, energy requirements, diet composition, size classes and energy density of the prey, and the distribution of predator feeding effort (Harwood and Croxall, 1988; Harwood, 1992).

Four species of seals are commonly found in the Gulf of St Lawrence. Grey seals (Halichoerus grypus) and harbour seals (Phoca vitulina) are found in this area throughout the year, while harp seals (Phoca groenlandica) and hooded seals (Cystophora cristata) are winter residents (Sergeant, 1976). The consumption of cod by grey seals in the Gulf of St. Lawrence has been estimated to be as high as 21000 tons, 17000 tons in the northern Gulf (Div. 4RS) and 4000 tons in the southern Gulf (Div. 4T). This cod consumption consists largely of pre-recruits to the commercial fishery (Hammill and Mohn, MS 1994). Cod consumption by harp seals in the northern Gulf of St. Lawrence has been estimated to be 54000 tons (95\% C.I. $=14000-102000)$ consisting primarily of fish 10-20 cm in length (Stenson et al., MS 1995a). Fish consumption has not been estimated for the remaining two species in the Gulf.

Hooded seals in the Gulf of St. Lawrence (Gulf stock) have been commercially exploited since the 19th century. Owing to the practice of killing the female in order to be able to harvest the pup, this population was severely depleted, and the commercial hunt ended in 1972 with the full protection of the Gulf stock (Reeves and Ling, 1981). Little information is available on their abundance, but an aerial survey flown in 1991 estimated pup production to be 2000 animals (Hammill et al., 1992).

Hooded seals are found primarily in Arctic waters, off the Greenland coasts and in Davis Strait during summer (Hammill, 1993). Tag returns indicate that hooded seals return to the Newfoundland and Gulf of St Lawrence regions during the autumn (Hammill, 1993). Comeau (1945) mentions killing a pregnant female during November 1893 and regularly seeing hooded seals in the $\mathrm{St}$ Lawrence Estuary near Baie Comeau in December, but they appeared to be most common in the St. Lawrence Estuary during the spring months of March-May. More recently, hooded seals have been seen around the Magdalen Islands during December (Cyr, Magdalen Islands, pers. comm.), among whelping grey seals, in the southern Gulf of St.
Lawrence during January (Hammill, pers. obs.) and in Cabot Strait during January and February (Cyr, Magdalen Islands, pers. comm.). Whelping occurs during March. A few pups are born within the harp seal patch near the Magdalen Islands, but the main hooded seal whelping patch is located off the north coast of Prince Edward Island. Females wean their pups after a short 4 day lactation period (Bowen $e t$ al., 1985; Kovacs and Lavigne, 1992). Information from satellite telemetry indicates that after leaving the whelping patch in late March, hooded seals move into the northern Gulf where the majority of animals remain, between the southwestern tip of Newfoundland and Baie Comeau, until mid-May (Stenson, Dept. Fisheries and Oceans, St. John's, Newfoundland, pers. comm.). After leaving the Gulf of St. Lawrence, hooded seals move along the south and east coast of Newfoundalnd, then traverse the Atlantic to moult off the southeastern coast of Greenland in June.

The objective of this study is to incorporate information on abundance, individual energy requirements, diet and the seasonal distribution of hooded seals to estimate their consumption of fish in the Gulf of St. Lawrence.

\section{Materials and Methods}

\section{Abundance}

Visual systematic strip transect surveys to estimate pup production were flown over the whelping patches in the southern Gulf of St. Lawrence in 1991 (Hammill et al., 1992) and in 1994. The surveys flown in March 1994 were in two parts but followed a similar design to the 1991 surveys. The first survey conducted 9-12 March was flown at an altitude of $46 \mathrm{~m}$ and using a total strip width of $70 \mathrm{~m}$. This survey covered an area to the north and northwest of the Magdalen Islands (Fig. 1). A second group of hooded seals, located north of Prince Edward Island (Fig. 1) was surveyed 19 March at an altitude of $61 \mathrm{~m}$ using a total strip width of $240 \mathrm{~m}$. Surveys to obtain information on the distribution of births were also flown over this second patch (Bowen et al., 1987). Data were analyzed using the methods described by Hammill et al. (1992).

The population dynamics were described by a Leslie Matrix model assuming that: the sex ratio at birth was 50:50, adult mortality was constant, mortality rates of males and females were similar, 


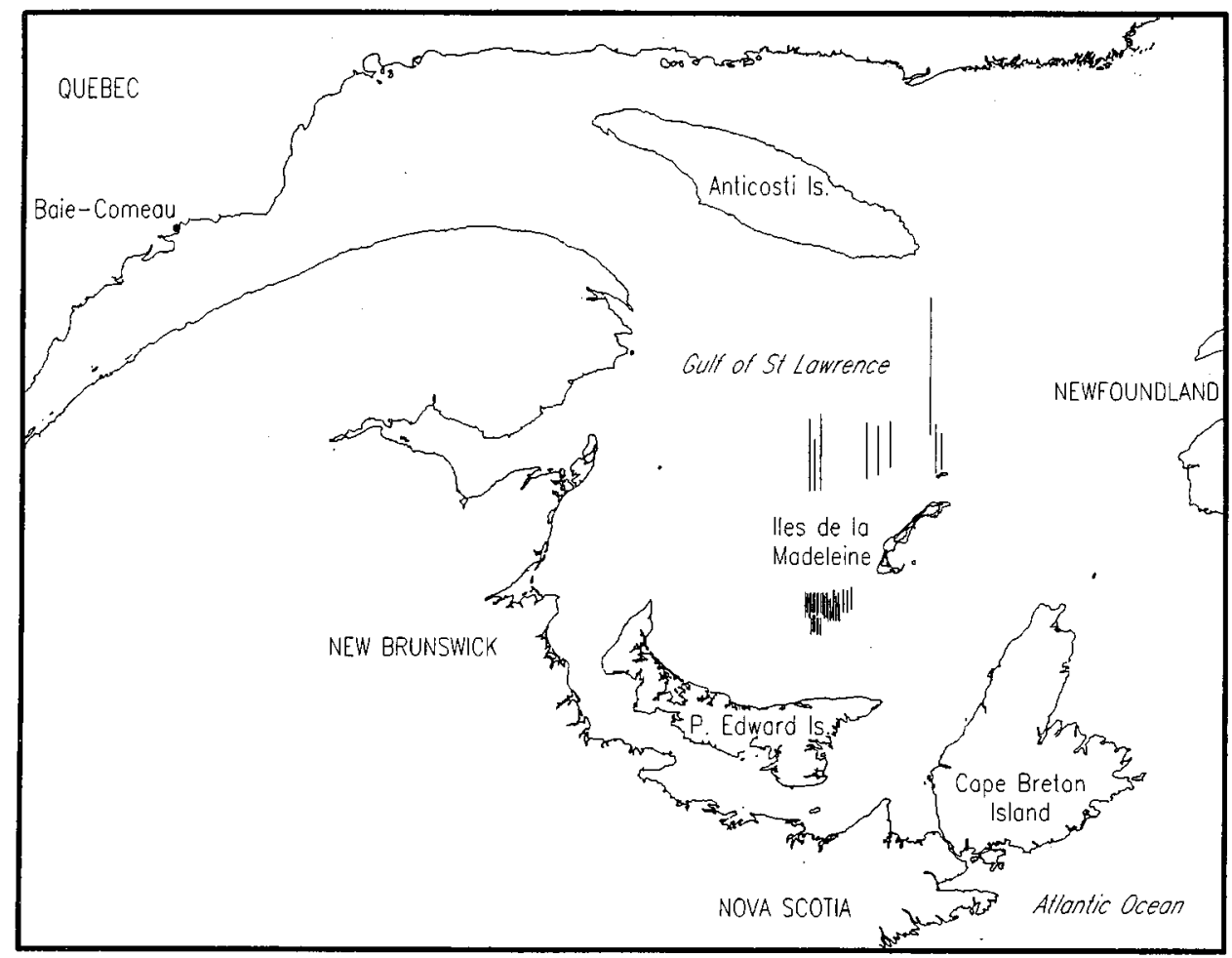

Fig. 1. Map of the Gulf of St. Lawrence showing location of transects flown during March 1994 aerial surveys.

first year mortality was three times the adult rate, pupping began at age 4 . Age specific reproductive rates used were $0.556,0.716,0.826,0.936,0.944$, $0.944,0.96$ and 0.98 , for ages 4 to $\geq 11$ years, respectively (Øritsland 1975). Simulations were run using values of 0.13 and 0.07 for adult mortality (Myers and Stenson, 1995). The model was permitted to run for 100 years to obtain a stable age distribution.

\section{Energy requirements}

Energy requirements were assumed to be constant throughout the year, except that breeding males were assumed not to feed between 8-29 March and females did not feed from 8-11 March. Individual energy requirements were calculated using:

$$
G E_{i}=G P_{i}\left(A_{i} 293 B M_{i}^{0.75}\right) / M e_{i}
$$

where $G E$ is daily gross energy intake at age $I$, and $G P$ is the additional energy required for growth. The growth premium $(G P)$ was set at 1.8, 1.6, 1.4, 1.3, $1.1,1.1$ and 1.0 for animals aged $0,1,2,3,4,5$ and $\geq 6$ years, respectively (Olesiuk, 1993). The activity factor $(A)$ was set at 2 to approximate the average daily energy requirements as a multiple of the basal metabolic rate $\left(293 B M_{i}^{0.75}\right.$, where $B M$ is body mass in $\mathrm{kg}$, Kleiber 1975). The metabolizable energy $\left(M E_{i}\right)$ was set at 0.83 (Ronald et al. 1984), assuming that hooded seals consumed only fish. Growth in body mass $\left(B M_{i}\right)$ at age $i$ was described using the Gompertz growth curves (Fig. 2) (Hammill et al., DFO, Quebec, Canada, unpubl. info.):

$$
\begin{aligned}
& B M_{\text {male }}=333.83(0.08)^{[16.41 \mathrm{i} / 26.50 \ln (0.08)]} \\
& B M_{\text {female }}=229.93(0.11)^{[9.16 \mathrm{i} / 24.84 \ln (0.11)]}
\end{aligned}
$$

where body mass is in $\mathrm{kg}$ and $i$ is the animal's age (years).

Animals were captured on the whelping patch by dropping a net over them. They were then immobilized with a combination of tiletamine $\mathrm{HCl}$ / Zolazepam $\mathrm{HCl}\left(\mathrm{Telazol}^{\circledR}\right)$ administered intramuscularly at a doseage of $0.7-1.0 \mathrm{ml} / 100 \mathrm{~kg}$. A lower incisor was then extracted, and age was determined by counting incremental growth layers in the cementum (Bernt et al., 1996). 


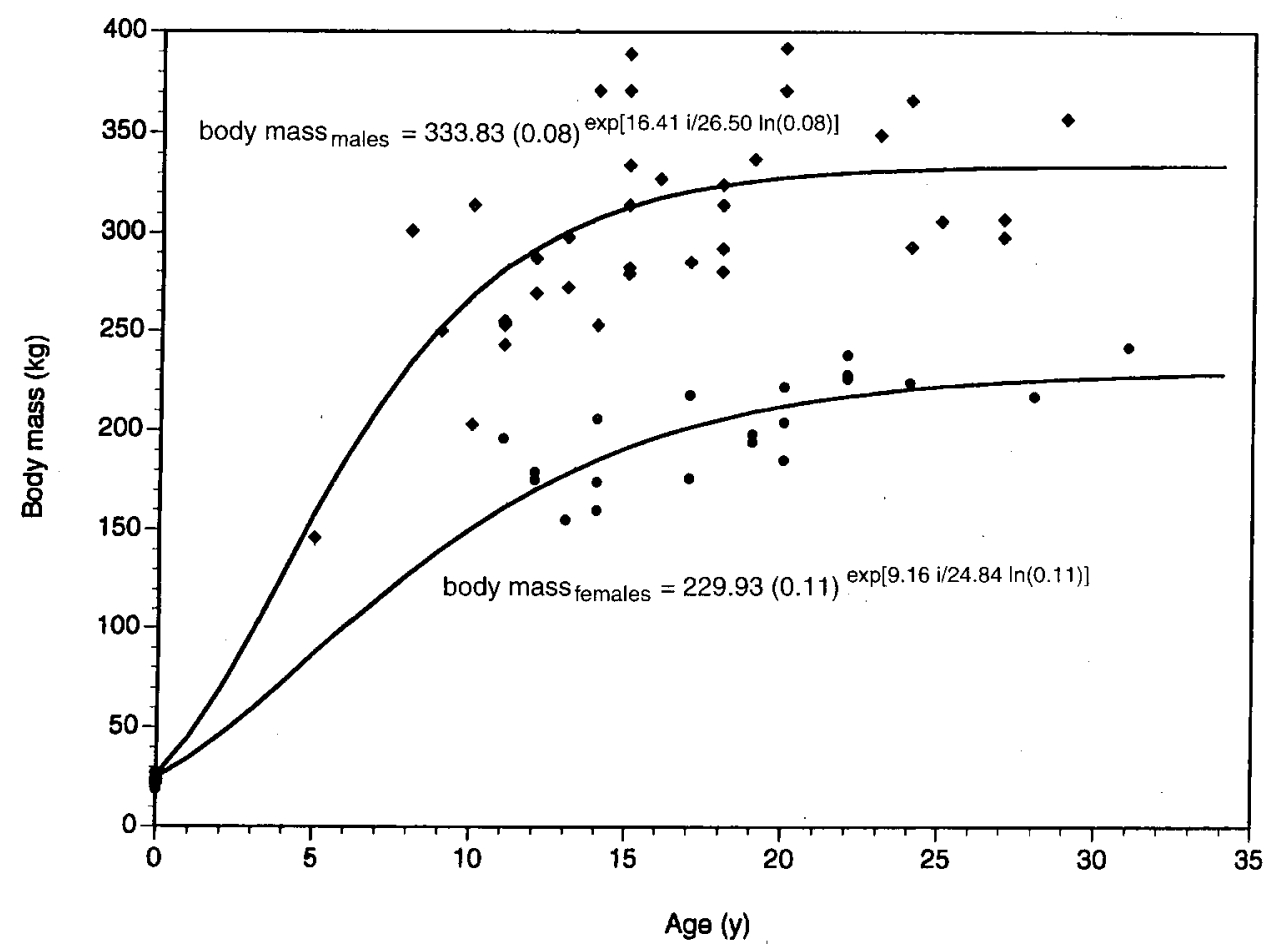

Fig. 2. Growth curves developed from male and female hooded seals captured on the whelping patch in March (Hammill et al., in prep.).

\section{Seasonal distribution}

In the following calculations all adults and $20 \%$ of juveniles were assumed to have moved into the Gulf of St. Lawrence on 1 December and remained there until 31 May. It was assumed that pups did not feed on fish in the Gulf.

\section{Diet composition}

Ross (MS 1993) recently examined the diet of Northwest Atlantic hooded seals, which included some samples from the south coast of Newfoundland. In the absence of any data for the Gulf of St. Lawrence population, it was assumed that the diet of Gulf hooded seals was similar (Table 1).

\section{Model sensitivity}

The sensitivity of the model was examined by altering model inputs by $10 \%$ and re-running it to observe the effects on the consumption estimates.

\section{Results}

Pup production estimated from the 1991 survey was $2006(S E=190)$. In 1994, three hooded seal pups were seen on 9 transects flown over a whelping patch located to the north of the Magdalen Islands (Fig. 1). This resulted in an estimate of 212 pups $(S E=91)$. Survey coverage was $1.7 \%$ of the available area. Twenty-eight transects were flown over the hooded seal whelping patch located just north of Prince Edward Island. Survey coverage was $19 \%$ and a total of 301 pups were counted. Estimated pup production before correcting for the seasonal distribution of births was $1583(S E=293)$.

Surveys to determine the distribution of births on the patch north of Prince Edward Island were conducted during 18-26 March, 1994 (Table 2). To calculate the proportions of animals on the ice during the survey, it was assumed that pupping began on 8 March. Using a Weibull distribution to fit the distribution of births over time it was estimated that $42 \%$ of the births had occurred prior to the survey. Applying this correction to the survey data for the patch located to the north of Prince Edward Island resulted in an estimate of 3766 (SE =970) pups. Adding in the estimate of 212 pups for the patch located north of the Magdalen Islands, total hooded seal pup production was estimated to be $3978(S E=974)$ in 1994 .

Changes in the hooded seal population were modelled for the years 1991-95. Using an initial pup production estimate of 2000 animals, and 
TABLE 1. Relative energy contribution and size frequency of common prey species of hooded seals $(N=67)$ collected from Newfoundland waters (Ross, MS 1993).

\begin{tabular}{lcccccc}
\hline \hline & $\begin{array}{c}\text { Energy } \\
\text { Sensity (kJ/g) }\end{array}$ & $\begin{array}{c}\text { Energy } \\
\text { contribution (\%) }\end{array}$ & \multicolumn{4}{c}{ Size frequency $(\%)$} \\
\cline { 5 - 7 } Greenland halibut & 6.2 & 53.0 & $30 \mathrm{~cm}$ & $21-30 \mathrm{~cm}$ & $31-40 \mathrm{~cm}$ & $>40 \mathrm{~cm}$ \\
Redfish & 4.4 & 17.2 & 0 & 32 & 40 & 12 \\
Arctic cod & 4.8 & 11.2 & 60 & 40 & - & - \\
Atlantic herring & 7.8 & 16.5 & 0 & 55 & 45 & - \\
Atlantic cod & 4.2 & 0.9 & 0 & 0 & 100 & 0 \\
Capelin & 6.8 & 0.4 & 100 & - & - & - \\
Squid & 3.8 & 0.8 & & - & - & - \\
\hline
\end{tabular}

TABLE 2. Number of hooded seal pups in different age dependent stages during March 1994. The development stages are based on Bowen et al. (1987).

\begin{tabular}{lcccc}
\hline \hline Day & Newborn & Thin & Fat & Solitary \\
\hline 18 & 2 & 52 & 61 & 36 \\
19 & 0 & 24 & 29 & 23 \\
20 & 2 & 35 & 50 & 64 \\
21 & 1 & 31 & 42 & 100 \\
24 & 2 & 5 & 2 & 12 \\
25 & 0 & 4 & 3 & 1 \\
26 & 0 & 5 & 11 & 44 \\
\hline
\end{tabular}

TABLE 3. Stable age distributions for a Gulf of St. Lawrence hooded seal population using different estimates of adult $\left(M_{a d}\right)$ and juvenile $\left(M_{j}\right)$ mortality rates.

\begin{tabular}{rrr}
\hline \hline Age & $\begin{array}{r}M_{a d}=0.13, \\
M_{j}=0.39\end{array}$ & $\begin{array}{r}M_{a d}=0.07, \\
M_{j}=0.21\end{array}$ \\
\hline 0 & 20.29 & 18.42 \\
1 & 12.08 & 13.14 \\
2 & 10.25 & 11.03 \\
3 & 8.76 & 9.21 \\
4 & 7.39 & 7.77 \\
5 & 6.28 & 6.52 \\
6 & 5.33 & 5.47 \\
7 & 4.53 & 4.59 \\
8 & 3.84 & 3.86 \\
9 & 3.26 & 3.24 \\
10 & 2.77 & 2.72 \\
11 & 2.35 & 2.28 \\
12 & 2.00 & 1.91 \\
13 & 1.70 & 1.61 \\
14 & 1.44 & 1.35 \\
15 & 1.22 & 1.13 \\
16 & 1.04 & 0.95 \\
17 & 0.88 & 0.80 \\
18 & 0.75 & 0.67 \\
19 & 0.64 & 0.56 \\
$\geq 20$ & 3.27 & 2.72 \\
\hline
\end{tabular}

mortality rates of 0.13 and 0.39 for adults and juveniles, respectively, the stable age distribution for the population consisted of $20 \%$ young of the year (Table 3). This population increased at $2.5 \%$ per year (Table 4). Mortality rates of 0.07 and 0.21 for adults and juveniles, respectively, decreased the proportion of pups in the population (Table 3 ) and enhanced the rate of increase to $10.8 \%$ per year (Table 4).

Estimates of population energy requirements for the years 1991-95 range from 2.94-3.19 $\times 10^{10} \mathrm{~kJ}$ per year to $3.25-4.81 \times 10^{10} \mathrm{~kJ}$ per year depending on the population trajectory used. Using mortality rates of 0.13 and 0.39 for adults and juveniles, respectively, total fish consumption would have increased from 5120 tons in 1991 to 5 644 tons in 1995 (Table 5). Using mortality rates 0.07 and 0.21 for adults and juveniles, respectively, total consumption would have increased from 5551 tons in 1991 to 8367 tons in 1995.

Changes in estimates of total population size, adult mortality rates, the time spent in the Gulf of St. Lawrence, and the activity factor resulted in changes in consumption estimates of $\geq 8 \%$ (Table 6 ). 
TABLE 4. Estimates of pup production and population size using adult mortality rates of 0.13 and 0.07 (Myers and Stenson, MS 1995) in the population model. Juvenile mortality rate was set at three times the adult mortality rate. The starting pup production was 2000 based on survey data (Hammill et al. 1992).

\begin{tabular}{cccccc}
\hline \hline \multirow{2}{*}{ Year } & \multicolumn{2}{c}{ Adult mortality $=0.13$} & & \multicolumn{2}{c}{ Adult mortality $=0.07$} \\
\cline { 2 - 3 } \cline { 5 - 6 } & $\begin{array}{c}\text { Pup } \\
\text { production }\end{array}$ & $\begin{array}{c}\text { Population } \\
\text { size }\end{array}$ & & $\begin{array}{c}\text { Pup } \\
\text { production }\end{array}$ & $\begin{array}{c}\text { Population } \\
\text { size }\end{array}$ \\
\hline 1991 & 2000 & 9858 & & 2000 & 10856 \\
1992 & 2049 & 10101 & & 2216 & 12028 \\
1993 & 2100 & 10350 & & 2455 & 13326 \\
1994 & 2152 & 10605 & & 2720 & 14765 \\
1995 & 2205 & 10867 & & 3014 & 16358 \\
\hline
\end{tabular}

TABLE 5. Estimated total fish consumption (tons) and consumption by species (tons) by hooded seals during the six month period that they were present in the Gulf of St. Lawrence. $M$ is the adult mortality rate used in the population model. Juvenile mortality was assumed to be 3 times that adult mortality rate.

\begin{tabular}{|c|c|c|c|c|c|c|c|c|c|c|}
\hline \multirow[b]{2}{*}{ Species } & \multicolumn{2}{|c|}{1991} & \multicolumn{2}{|c|}{1992} & \multicolumn{2}{|c|}{1993} & \multicolumn{2}{|c|}{1994} & \multicolumn{2}{|c|}{1995} \\
\hline & $M=0.13$ & $M=0.07$ & $M=0.13$ & $M=0.07$ & $M=0.13$ & $M=0.07$ & $M=0.13$ & $M=0.07$ & $M=0.13$ & $M=0.07$ \\
\hline Greenland halibut & 2517 & 2729 & 2579 & 3024 & 2643 & 3350 & 2708 & 3712 & 2774 & 4113 \\
\hline Redfish & 1151 & 1248 & 1179 & 1383 & 1208 & 1532 & 1238 & 1697 & 1269 & 1881 \\
\hline Arctic cod & 687 & 745 & 704 & 825 & 721 & 914 & 739 & 1013 & 757 & 1123 \\
\hline Atlantic herring & 623 & 675 & 638 & 748 & 654 & 829 & 670 & 919 & 687 & 1018 \\
\hline Atlantic cod & 63 & 68 & 65 & 76 & 66 & 84 & 68 & 93 & 70 & 103 \\
\hline Capelin & 17 & 19 & 18 & 21 & 18 & 23 & 19 & 26 & 19 & 28 \\
\hline Squid & 62 & 67 & 64 & 74 & 65 & 83 & 67 & 91 & 68 & 101 \\
\hline Total & 5120 & 5551 & 5247 & 6151 & 5375 & 6815 & 5509 & 7551 & 5644 & 8367 \\
\hline
\end{tabular}

TABLE 6. Effects of a $10 \%$ change in model parameters on the estimated total fish consumption by hooded seals in the Gulf of St. Lawrence.

\begin{tabular}{lrl}
\hline \hline \multicolumn{1}{c}{ Parameter } & Effect $(\%)$ \\
\hline Population size & 10 \\
Adult mortality rates & 8 \\
Juvenile mortality rates & 1 \\
Residency time in the Gulf of St. Lawrence & 10 \\
Proportion of juveniles in the Gulf & 4 \\
Proportion of adults in the Gulf & 6 & \\
Activity factor & 10 & \\
Growth premium & 2 & \\
Growth rate constant in Gompertz curve & 4 & \\
Asymptotic weight & 8 & \\
Caloric density of fish & 9 change in species \\
& \multicolumn{2}{c}{ composition, 2-4 change } \\
& \multicolumn{2}{c}{ in total fish consumption } \\
\hline
\end{tabular}


The model was less sensitive to changes in juvenile mortality rates, the proportion of juveniles or adults in the Gulf of St. Lawrence, the growth premium applied to the juvenile classes and changes in asymptotic weight estimates from the growth curve. Changes of $10 \%$ in diet composition or caloric density of fish had a major impact on estimated fish consumption by species, but had little effect on total fish consumption (2-4\%).

\section{Discussion}

Many factors can affect fish stocks levels. In the absence of fishing mortality, the delayed recovery in commercial fish stocks may be attributed to reproductive failure or high natural mortality rates. Mortality rates, particularly among the pre-recruit age classes, are difficult to estimate directly. An alternative is to estimate mortality indirectly by estimating losses to the population from predation, starvation or other sources. An estimate of total natural mortality could then be obtained by summing mortality from the different components. In this study, our objective was to estimate fish consumption by hooded seals. In order to do this several assumptions were made during model development, which may or may not be realistic. In the sensitivity analysis, we attempted to examine the effects of some of the uncertainty in model parameters on the consumption estimates.

The Gulf of St. Lawrence hooded seal population is relatively small and very little information is available with respect to the inputs required to develop our model. Consequently, information from other populations were used with the assumptions that: trends in population size are adequately described by the survey data and population dynamics model, only a small fraction of the juvenile population is in the Gulf of St. Lawrence during winter and hooded seals are confined to the northern part of the Gulf of St. Lawrence during the period December to May. It was also assumed that hooded seal energy requirements can be described using a simple energy-budget model and that diets of hooded seals in the Gulf of St. Lawrence are similar to those from the south and east coasts of Newfoundland and Labrador.

The sensitivity analysis indicated that changes of $10 \%$ in the hooded seal population size, adult mortality rates, the residency period in the Gulf of St. Lawrence, and the activity factor in the energy budget model had the greatest effects on parameter estimates. Changes in the caloric density of the prey and proportion of a fish species in the diet had little effect on overall consumption, but had important effects on consumption estimates for individual fish species. The impact of other factors such as changes in juvenile hooded seal mortality rates, the proportion of juveniles in the Gulf of St. Lawrence, estimates of the growth premium, and growth curve parameters were less critical. We did not attempt to model seasonal changes in energy requirements in the model owing to a lack of information on seasonal changes in body mass for different age-classes.

Using a different approach, Shelton et al. (1997) examined uncertainty associated with model inputs on fish consumption by harp seals, by drawing samples from an assumed distribution of parameter estimates taken from the literature. These parameters included estimates of population size, residency period, energy requirements and diet composition. They found that uncertainty in the amount of cod consumed was affected most by the variability in diet composition (Coefficent of variation $=28 \%$ ), followed by energy requirements and residency time $(\mathrm{CV}=12 \%)$, while the uncertainty in estimates of population size $(\mathrm{CV}=$ $4 \%$ ) had relatively little effect.

The apparent contradiction between the two studies on the relative importance of population size is due to the different approaches used. The approach used by Shelton et al. (1997) reflects the low year-to-year changes that can be expected in predator population size and the relative ease with which this information can be obtained. In the Gulf of St. Lawrence, only two estimates of hooded seal pup production were available. Although these two estimates differed by more than one standard error, this was not significant at the $95 \%$ confidence level. Given the relatively small size of this population, and the relatively simple logistics of working in the Gulf of St. Lawrence, monitoring pup production every three to four years would be relatively inexpensive and worthwhile.

In this study it was assumed that hooded seals moved into the northern Gulf of St. Lawrence on 1 December and left the area on 31 May. This assumption was based on early observations by Comeau (1945), 2 incidental sightings by one of us $(\mathrm{MOH})$ of hooded seals among whelping grey seals in the southern Gulf of St. Lawrence, and anecdotal 
reports from commercial fishermen of hooded seal sightings in Cabot Strait during January. Information on the timing of departure of hooded seals from the Gulf of St. Lawrence was based on the movements of adults using satellite tags deployed on the whelping patch during March (Stenson, Dept. Fisheries and Oceans, St John's, Newfoundland, pers. comm.). Owing to the pelagic nature of hooded seals and the lack of offshore activity during winter months due to ice cover, it is unlikely that much more information can be obtained about residency times of the different components of the population in the Gulf of St. Lawrence.

Estimates of energy requirements depend on the activity factor applied to the basal metabolic rate equation. The estimated value of 2 here is at the low end of a range of values (1.7 to 3 ) from studies on captive and wild marine mammals (Worthy, 1990). Improvements to this estimate will require more information on the time and energy values to be allocated to resting and active swimming hooded seals.

Comeau (1945) reported that the Gulf of St. Lawrence hooded seals consumed winter flounder (Pseudopleuronectes americanus), capelin (Mallotus villosus), sculpin (Myxocephalus sp.), herring (Clupea harengus) and haddock (Melanogrammus aeglefinus), but unfortunately there were no quantitative diet data available for the area. Assuming that the diet composition was similar to that of hooded seals on the south and east coast of Newfoundland, it appears that the Gulf of St. Lawrence hooded seals do not consume much Atlantic cod (Gadus morhua), but they may cause significant mortality to Greenland halibut (Reinhartius hippoglossoides) and redfish (Sebastes sp.). Given the small size of this marine mammal stock and the pelagic nature of their distribution, diet composition from reconstruction of stomach contents or analyses of scats are not appropriate. However, new techniques such as analyses of fatty acids in the blubber (Iverson, 1993) and stable-isotope ratios (Hobson et al., 1996) may provide some insight. Blubber biopsies, and different tissue samples from live animals on the whelping patch in March could provide diet information over time periods of several hours, days or months.

This study suggests that hooded seals in the Gulf of St. Lawrence may have consumed as much as 5 600-8 400 tons of fish in 1995, including significant quantities of Greenland halibut and redfish. The total allowable catch for Greenland halibut in this area is 4000 tons while the redfish fishery is currently closed due to low stock levels. Thus, the relatively large amounts of these species consumed by hooded seals would appear to be of the same order of magnitude or exceed the commercial harvest. However, this consumption consists primarily of prerecruits to the commercial fishery (Ross, 1993). Unfortunately, since there is no information available on mortality rates for these prerecruit ageclasses, it is not possible to determine whether predation by hooded seals has a significant effect on these fish stocks compared to other sources of mortality. Future research needs to address this question of mortality among younger age-classes of commercial fish. In the meantime, information on diet composition of hooded seals in the Gulf of St. Lawrence is also required in order to refine these estimates of consumption.

\section{Acknowledgements}

We thank V. Lesage and B. Sellars for help with the seal captures. R. Folk and B. Sellars kept us on line and ensured that we made it to the hooded seal patch and back. R. A. Myers completed the calculations for the birthing ogive. J.-F. Gosselin helped with the figures. Financial support was provided by the Dept. of Fisheries and Oceans, the Norwegian Polar Institute (C.L.), a NATO Collaborative and NSERC Research Grant to K.M.K.

\section{References}

ANON. 1995. Overview of the status of Canadian managed groundfish stocks in the Gulf of St. Lawrence and in the Canadian Atlantic. DFO Atl. Fish. Stock Status Rep., No. 3E. 19 p.

BERNT, K. E., M. O. HAMMILL, and K. M. KOVACS. 1996. Age estimation of grey seals (Halichoerus grypus) using incisors. Marine Mammal Science, 12: 476-482.

BOWEN, W. D., O.T. OFTEDAL, and D. J. BONESS. 1985. Birth to weaning in 4 days: remarkable growth in the hooded seal, Cystophora cristata. Can. J. Zool., 63: 2841-2846.

BOWEN, W. D., R. A. MYERS, and K. HAY. 1987. Abundance estimation of a dispersed dynamic population: hooded seal (Cystophora cristata) in the Northwest Atlantic. Can. J. Fish. Aquat. Sci., 44: 282-295.

COMEAU, N. A. 1945. La vie et sport sur la cote nord $\mathrm{du}$ bas St. Laurent et du Golfe. Edition Garneau, 
Quebec, Qc. 372 p.

HAMMILL, M.O. 1993. Seasonal movements of hooded seals tagged in the Gulf of St Lawrence, Canada. Polar Biol., 13: 307-310.

HAMMILL, M. O., and B. MOHN. MS 1994. A model of grey seal predation on Atlantic cod on the Scotian Shelf and Gulf of St. Lawrence. DFO Atl. Fish. Res. Doc., No. 75, 25 p.

HAMMILL, M. O., G. B. STENSON, and R. A. MYERS. 1992. Hooded seal (Cystophora cristata) pup production in the Gulf of St. Lawrence. Can. J. Fish. Aquat. Sci., 49: 2546-2550.

HARWOOD, J. 1992. Assessing the competitive effects of marine mammal predation on commercial fisheries. S. Afr. J. mar. Sci., 12: 689-693.

HARWOOD, J., and J. P. CROXALL. 1988. The assessment of competition between seals anc commercial fisheries in the North Sea and the Antarctic. Mar. Mamm. Sci., 4: 13-33.

HOBSON, K. A., D. M. SCHELL, D. RENOUFF, and E. NOSEWORTHY. 1996. Stable carbon and nitrogen isotopic fractionation between diet and tissues of captive seals: implications for dietary reconstructions involving marine mammals. Can. J. Fish. Aquat. Sci., 53: 528-533.

IVERSON, S. J. 1993. Milk secretion in marine mammals in relation to foraging: can milk fatty acids predict diet? In: Marine mammals: Advances in behavioural and population biology. I. L. Boyd (ed.). The Zoological Society of London, Clarendon Press, Oxford, U. K. p. 263-291.

KLEIBER, M. 1975. The fire of life: An introduction to animal energetics. (2nd ed.) R.E. Kreiger Publishing Co., New York.

KOVACS, K. M., and D. M. Lavigne. 1992. Masstransfer efficiency between hooded seal (Cystophora cristata) mothers and their pups in the Gulf of St. Lawrence. Can. J. Zool., 70: 1315-1320.
MYERS, R. A., and G. B. STENSON. MS 1995. Replacement yield of hooded seals in the Northwest Atlantic. NAFO SCR Doc., No. 40, Serial No. N2549, 3 p.

OLESIUK, P. F. 1993. Annual prey consumption by harbour seals (Phoca vitulina) in the Strait of Georgia, British Columbia. Fisheries Bulletin (Dublin) 91: 491-515.

ØRITSLAND, T. 1975, Sexual maturity and reproductive performance of female hooded seals at Newfoundland. ICNAF Res. Bull., 11: 37-41.

REEVES, R .R., and J. K. LING. 1981. Hooded seal, Cystophora cristata, Erxleben, 1777. In: Handbook of Marine Mammals. Vol. 2. Seals. S. H. Ridgeway and R. J. Harrison (eds.). Academic Press, Toronto, ON., p. 171-194.

RONALD, K., K. M. KIEVER, F. W. BEAMISH, and R. FRANK. 1984. Energy requirements for maintenance and faecal and urinary losses of the grey seal (Halichoerus grypus). Can. J. Zool., 62: 1101-1105.

ROSS, S. MS 1993. Food and feeding of the hooded seal in Newfoundland. MSc. Thesis. Memorial University, St. John's Newfoundland.

SHELTON, P. A., W. G. WARREN, G. B. STENSON, and J. W. LAWSON. 1996. Quantifying some of the major sources of uncertainty associated with estimates of harp seal prey consumption. Part II: Uncertainty in consumption estimates associated with population size, residency, energy requirements and diet. J. Northw. Atl. Fish. Sci., 22: 303-315.

STENSON, G. B., M. O. HAMMILL, and J. W. LAWSON. MS 1995a. Predation of Atlantic cod, Capelin, and Arctic cod by harp seals in Atlantic Canada. DFO Atl. Fish. Res. Doc., No. 72, 29 p.

WORTHY, G. A. J. 1990. Nutritional energetics for marine mammals: Addendums. In: CRC handbook of marine mammal medicine: Health, disease and rehabilitation. L. A. Dierauf (ed.). Boca Raton, Florida: CRC Press, p. 489-520. 